\title{
The Appeal to Human Rights in Arbitration and International Investment Agreements*
}

\section{El recurso a los derechos humanos en arbitrajes y acuerdos internacionales de inversión}

\section{Yadira Castillo**}

\begin{abstract}
Sumario: I. Introduction. II. Modest inclusion of Human Rights in International Investment Agreements. III. Bilateral Treaties for Promotion and Protection of Foreign Investment. IV. The appeal to Human Rights as a defense mechanism of the parties to the arbitration of foreign investment. V. Conclusions. VI. Bibliography.
\end{abstract}

* Artículo recibido el 25 de mayo de 2011 y aprobado para publicación el 28 de septiembre de 2011

This article is the outcome of an internship I did at UNCTAD - Geneve, Switzertland in May-June, 2010. The internship was called "Virtual Institute Fellowship programme.” I would like to thank the group of experts at UNCTAD for all their comments and support: Vlasta Macku, Evelyn Benedicte, Elisabeth Tuerk, Hamed El-Kady, Ann Joubin-Bret, and Diana Rosert . I would also like to thank the support given by Los Andes University-Bogota in the Program Doctorate in Law and my Thesis Director, Rene Fernando Urueña (Andes University) for all his suggestions and support.

** Lawyer, LL.M. In Administrative Law, student of PhD program in Law at Universidad de los Andes Bogotá Colombia and Assistant Professor of International Public Law in Andes University. 
RESUMEN: Este artículo estudia las relaciones entre DH, soft law e instrumentos de Inversión extranjera, así como entre DH y arbitrajes de inversión. El artículo comprende dos escenarios. Bajo el primero, abordo el impacto sobre las ETN de la incorporación del soft law en los AII. Bajo el segundo, el artículo refleja que el recurso indirecto por parte de los estados y el inversor a un lenguaje de los DH en los arbitrajes de inversión, puede tener un doble propósito: por un lado, empodera a los inversores extranjeros haciendo más visible su situación de debilidad frente al estado. Del otro, la remisión hecha por los estados propone un cambio en la lógica de los arbitrajes de inversión: el carácter proteccionista de los TBIs se ve cuestionado por la protección a intereses públicos protegidos por los estados, como los derechos de las minorías.

Palabras claves: Soft law, Acuerdos Internacionales de Inversión AII, responsabilidad social corporativa RSC, tratados bilaterales de inversión TBI, arbitraje de inversión extranjera, derechos humanos DH, derechos de las minorías, empresas transnacionales ETN.

ABSTRACT:This article studies the relationship among Human-Rights (HR), soft law, and International Investment tools, and between $H R$ and investment arbitrations. It suggests two stages. In the first, it will discuss the impact on TNCs that the incorporation of soft law tools on international investments can have. The second stage shows that the indirect use of the HR language by the investor and the state in the arbitration of foreign investments can have a dual purpose. On the one hand, it empowers foreign investors by making their weak situation in relation to the state more visible. On the other hand, the remission made by the states proposes a change in the logic of investment arbitrations: the protectionist character of the BITs is challenged by the protection of public interests protected by the states, such as the rights of minorities.

Descriptors: Soft law, International Investment Agreements IIAs, Corporate Social Responsibility CSR, Bilateral Investment Treaties BITs, investment arbitration, human rights, minority rights, transnational corporations TNCs.

RÉSUMÉ: Cet article étude les relations entre les droits de l'homme, droit flou et les instruments d'inversion étrangère, et aussi les relations entre les droits de l'homme et les arbitrages d'inversion. L'article a deux contextes. Dans le premier contexte, je parle de l'impact sur le FM de l'incorporation du droit flou dans les AII. Dans le deuxième, l'article reflète que le recours indirecte que les états et l'investisseur font d'un langage des droits de l'homme aux arbitrages d'inversion peut avoir un double objectif: d'un côté, il donne de pouvoir aux investisseurs étrangères en faisant plus visible leur situation de faiblesse en face de l'état. D'un autre côté, la rémission fait par les états propose un changement de la logique des arbitrages d'inversion: le caractère protectionniste des TBIs est remis en question par la protection des intérêts publiques protégés par les états, par exemple les droits des minorités.

Mots clés: droit flou, Accords Internationaux d'Inversion AII, Responsabilité Social Corporatif RSC, Traités Bilatéraux d'inversion TBI, arbitrage d'inversion étrangère, droits de l'homme, droits des minorités, firmes multinationaux FM. 


\section{INTRODUCTION}

In recent decades, international law - IL — has advanced in the field of foreign investment regulation through the International Investments Treaties - IIAs_-, among which are the Bilateral Investments Treaties - BITs - ${ }^{1}$ IIAs are multifaceted instruments, ${ }^{2}$ which in part can be understood as the creation of systems of protection and attraction of foreign investors rather than imposing obligations upon them. The design of investment agreements as an investor protection vehicle was marked on the arrangements agreed to before the $90 \mathrm{~s}$. Until then, it was very common to find agreements on investments without any reference or statement of commitments in the field of human rights, which is the topic of interest of this paper. After that date, there have been changes in the Human Rights - HR — and business, ${ }^{3}$ manifested in two scenarios: first, a trend in investment agreements (Comesa, CARIFORUM, the FTA between Canada and Colombia) in the inclusion of commitments both for the contracting states and investors on issues of human rights, which results in Corporate Social Responsibility - CSR - policies, and the second in the use of indirect language related to HR both by the states and investors in international investment arbitration.

Progress in relation to the inclusion in IIAs of HR does not operate the same way in the BITs. In the formulation of BITs, which are not excluded from the provisions of IIAs in general, including HR issues is not a priority. BITs can be seen as a constraint on the states, because of

Nowadays we can find three IIA modes: 1. Bilateral treaties, 2.- investment regional treaties signed by state groups that belong to a particular region and 3.- the chapters integrated to the investment and trade agreements that can be signed regionally or bilaterally. BIT number was higher than 2600 at the end of 2007; they are the most common type of IIA; approximately a $47 \%$ of IIAs are BITs. United Nations Conference on Trade and Development, International Investment Agreements: Assessment, Challenges and Path to Continue. Collection of publications of the UNCTAD on topics related to investment international policies on development, New York and Geneva, UNCTAD, 2008, p. 16.

2 Besides foreign investment topics, other regulatory topics are: goods and services trade, intellectual property rights, competition policies, public sector recruitment. Ibidem, p. 20-1.

3 Mann, H., International Investments Agreements, Business and Human rights: Key Issues and Opportunities, Canada, International Institute for Sustainable Development, 2008, pp. 9 y 10. 
its purpose, which is to become a protectionist tool rather than a tax obligation for the investor. Thus, the design of these agreements is read as a limit on the obligation the states have to protect and promote HR towards the actions or omissions of individuals. ${ }^{4}$ This brief presentation generated the following questions: Is the HR modest inclusion in international investment agreements sufficient to address the developments in CSR? Should we move toward the inclusion of a clause in the BITs responsibility for violations of the HR by the top of investors? Would it be said that the indirect reference to the language of the HR made by states in investment arbitrations reduces the weak status of investors? If the answer is affirmative, is there any change in the dynamics of investment arbitrations and BITs?

According to the above questions, this paper suggests two arguments. In the first argument, it will discuss two scenarios: in the first, it points out that companies involve soft law within their activities by designing CSR policies with HR content, regardless of whether or not they are in an IIA. Then the impact of the preventive inclusion of the HR in IIA fails to transform a scenario in which companies tend to include CSR policies in their activities motivated toward the goal of protecting or enhancing their reputation. In the second scenario, it notes that the inclusion of the States in the IIA of human rights allow them to respond progressively to community concerns regarding the challenges of the activities of non-state actors such as Transnational Corporations - TNCs - , but does not allow them to resolve issues related to their legal responsibility for violation of the HR. It also shows that the inclusion of such issues promotes the building and strengthening of state leadership in the international community and in turn, of their identity. The second argument shows that the indirect use of the HR language by investor and state in the arbitration of foreign investments can have a dual purpose: On the one hand, it can empower foreign investors making their weak situation in relation to the state more visible. The remission made in indirect language by the states supported in the HR or the rhetoric created around them, thus allowing a change to the logic of investment arbitrations, in the sense that the protectionist nature of

\footnotetext{
Ibidem, p. 8.
} 
the BITs is challenged by the protection to the fundamental interests protected by the states, such as the rights of minorities.

It attempts to answer the questions through the above arguments it lets to say that so far the approaches ${ }^{5}$ have not gone deep in allusion to

5 The Paper Select Recent Developments in IIA Arbitration and Human Rights II A monitor 2009 Geneva: UNCTAD, 2009 points out that the IIA remain silent with respect to HR topics and do not make any detailed reference to the obligations of the States regarding HR and do not mention investors. However, it indicates that in spite of the fact that there is an absence of HR dispositions, it is true that HR topics have emerged in arbitrations. Investigating the possibility an investor has to use arbitration in case he has been accused of violating Ius Cogens regulations.

The essay Investment Agreements, Business and Human Rights: Key Issues and Opportunities, Canada: International Institute for Sustainable Development 2008, written by Howard Mann, firstly emphasis the relationship between HR and investment getting support from the studies of the HR and transnational companies special Representative, John Ruggie. Secondly, he points out the inclusion of HR in international agreements, checks the Project of the Institute for Sustainable Development by investigating the demandability towards the investors regarding obligations related to HR, and the tensions within the IIA so that States can regulate their demanding commitments in HR. He organizes his study using arbitrations and HR.

Luke Eric Peterson and Kevin Gray in International Human Rights in Bilateral Investment Treaties and in Investment Treaty Arbitration Canada: International Institute for Sustainable Development, 2003 explores the implications of HR in the arbitrations based on BITs taking into account the complicity of the states and investors, the tensions with the Ius Cogens regulations, the figure of Amicus, the defense made by the States in investment arbitrations with the support of HR, among other topics.

James Harrison in Human Rights Arguments in Amicus Curiae Submissions: Promoting Social Justice. In: Human Rights in International Investment law and Arbitration. New York: Oxford University Press, 2009, develops a study on the figure of Amicus within the arbitrations dealing with its importance, limits, reasons to be accepted.

Moshe, Hirsch in Investment Tribunals and Human Rights. Divergent Paths. In: Human Rights in International Investment Law and Arbitration. New York: Oxford University Press, 2009, accounts for the assymetric relationship between the investor and the states and as a consequence of the complexity to include burdens to HR. He also points out that the IHL is not related to the investment international law because the first belongs to public rights. The writer also adds that public rights develop international mechanisms for their protection and demand that they fall into the responsibility of the states, meanwhile, investment international rights associated to private rights and the differences that emerge are commercial. This means that the remission to human rights is overlooked in arbitration. He assures that the arbitration courts have not accepted the specific provisions exam of IHL referred by both parties, except in the case Mondev.

Pierre-Marie, Dupuy, in "Unification Rather than Fragmentation of International Law? The Case of International Investment Law and Human Rights Law." In: Human Rights in International Investment law and Arbitration. New York: Oxford University Press, 2009 shows di- 
the IIA relationship with human rights and CSR, nor in the changes that may occur in investor-state relationship as a result of the defense of the states of public interest supported in minority rights. Therefore, the interest of this paper is to contribute with two aspects to previous investigations: 1 . To take a look at the relevance of the inclusion of preventive language in the context of the HR in IIAs. 2. To focus on delivering a lecture in connection with the use of indirect language or logic of the HR in international arbitration of investment in terms of investors and the state, thereby seeking to question the parameters under which they analyze BITs and arbitrations.

With the purpose to clarify terms in this essay, for soft law in the context of TNCs it will be understood as the adoption made by TNCs under the rhetoric of SCR related to principles or guidelines with the purpose of guiding the deployment of their activities taking these guidelines as a mechanism of auto regulation and of building of their reputation. Also, it point outs that by soft law and HR in the context of IIA it means the requirement of the states in the IIA to non-state actors as TNCs with the purpose to incorporate in their activities good practices of social corporate responsibility related to economic, social and cultural rights ESCR, certain civil rights and environmental rights. This happens without using any language which would establish mandatory enforcement of this dynamic, and therefore gaining real preventive connotations. In that context it is pertinent to refer to modest inclusion of HR. Finally, the mention to the appeal of HR as a mechanism of defense of the parties in the investment arbitration can be understood in two contexts: under the first, the states, without referring directly to the hard core of ESCR, can create a coherent defense through the allusion of public fundamental interest of the minority people. In that sense, the defense for the states underpinned in the indirect language of HR or in the rhetoric created around them proposes a change in the logic of investment arbitration. Under the second context, the investor can make more obvious his weakness status in related to the state, if he decides to articulate the rights in the BITS with the indirect language around HR.

fferences in the division between IL and IL of investments, as well as IL of investments and International Human Rigths, according to his criterion this division is not visible, and there is a tendency for integration. 
For the above purposes, this article is divided into three parts. First, it will discuss the implications of the inclusion of the HR in IIAs, considering the perspective of states and businesses. It should be clarified at this point that much of our approach to the subject is linked to a sociolegal study related to the introduction of soft law, understood as CSR initiatives by the mining companies in Colombia. The second part deals with the main characteristics of the BITs. Finally, the third part presents a study in two stages. In the first, an analyzation of the systematic integration of public international law-PIL-to investment law will be made. In the second, the goal is to determine whether the HR is an artifact of empowerment of companies or otherwise when they are used by states, and in cases involving far-reaching public interest, can transform the protectionist nature of the BITs. In this way, it will study two awards: Glamis Gold vs United States and Piero Foresti vs South Africa, entering in the study of the application of the Amicus presented in this case.

\section{MODEST INCLUSION OF HUMAN RightS \\ IN INTERNATIONAL INVESTMENT AGREEMENTS}

The purpose in this part of the paper is to articulate soft law and international investment agreements, taking into account HR and its modest inclusion. By modest inclusion it means to include the requirement made in the agreements to non-state actors such as TNCs through the states to voluntarily incorporate HR into their activities, without using any language which would establish mandatory enforcement of this concept, and therefore gaining real preventive connotations. It will show two scenarios: in the first, it indicates that the TNCs include soft law in their activities through the development of CSR policies- with high HR content,-regardless of whether or not they are in an IIA. This demonstrates that the preventive impact of the inclusion of HR in investment agreements can not "transform" a scenario in which companies normally with or without international investment agreements include CSR policies in their activities as a means to attract and retain their business viability. 
The second scenario demonstrates that the intention of states in formulating modestly HR language in IIA does not address the consequences for possible violations by these same TNCs. The inclusion of human rights issues allows states to progressively respond to community concerns about the challenges of the activities of non-state actors such as TNCs. Likewise, the inclusion of such issues, promotes the building and strengthening of leadership in the international community and in turn, an enhancement of identity. In that order, a first approach will consider the impact of these policies compared to extractive industries, and in a second stage, it will refer to the modest inclusion of HR in IIAs. Clarifying further, that the impacts of soft law incorporated by these companies will be presented using our empirical approach on this issue.

\section{Soft law and its inclusion in the activities of transnational corporations}

For purposes of clarity regarding the impact of soft law in relation to mining companies, at first it will discuss its content and in the second, it will present a socio-legal research. Thus, soft law, characterized by their lack of legal entailment, which has its source in both the willingness of states $^{6}$ as well as the non-state actors, can respond to the joint efforts between governments and non-state actors at the time of its creation, as well as its implementation. It is seen in part as the enunciation of guidelines or goals to be achieved in the future. Rather than understand the current obligations or requirements, it is configured as programmatic frameworks. ${ }^{7}$ Similarly, for others, it serves as a non-binding instrument, with the exception of appearing as statements indicative of a willingless to perform such behavior. ${ }^{8}$ Others tend to associate this with

\footnotetext{
6 Among them we find initiatives such as Global Compact, which originated in the UN in 2000, the Draft fundamental Human Rights principles for Business Enterprises, formulated by the UN work team-Sub- commission on the promotion and protection of Human Rights 2001, social responsibility principles of the transnational companies formulated by the UNCTAD, the guidelines for the transnational companies formulated by the OECD.

7 Dupuy, P., "Soft law and the International Law of the Environment", Michigan Journal of International Law, vol 3, 1991, p. 56

8 Williamson, R., "Hard Law, Soft Law and Non-Law in Multilateral Arms Control: some compliance hypotheses”, Chicago Journal International Law, vol. 4, 2003, p. 63.
} 
a vision toward legalization, which refer to the degree of accuracy, and obligations contained in the rules. ${ }^{9}$

Their lack of entailment allows for much more flexible compliance, thereby reducing complex procedures that would make its implementation more complex (international adoption by treaty, internal implementation). This flexibility makes it feasible to establish commitments to states and private parties in the absence of binding legal instruments. In connection with TNCs and specially with extractive industries, the use of soft law instruments is performed for the protection of reputation and prevention. Overall, the initiatives that they incorporate into their activities actually supports them to indicate that the lack of any legally binding instrument or enforceable actions against them is not obstacle to demonstrate their commitment to the protection and guarantee of HR. Nevertheless, the initiatives are insuficient (judicially) in the case of human rights violations. In this respect, the next step is to expose the empirical research mentioned above.

The research consisted in qualitatively studying the receptivity (the strengths, weaknesses, implementation alternatives, significance and relevance to the companies, the implications for them, the effectiveness of initiatives or inaction) of four instruments of soft law linked in four non-renewable resource extractive TNCs (gold and oil) with subsidiaries in Colombia, which for reasons of confidentiality we will identify as $\mathrm{A},{ }^{10} \mathrm{~B},{ }^{11} \mathrm{C}^{12}$ y $\mathrm{D}^{13}$ through a socio-legal aproximation. Soft law instruments on which this paper will not go into detail are: el Global

9 Karmel, R., and Kelly C., "The Hardening of Soft Law In Securities Regulation”, Brook Journal International Law, vol. 34, 2008-2009, p. 895.

10 Oil and Gas extractive multinational company. It has operations in: North America, The North Sea, South east Asia, Peru, Algeria, Poland, and Colombia.

11 It is a gold extractive multinational company. It has operations in: Africa, North America and South Australia.

12 It is a gas and oil company. It has operations in: North Africa, Middle East and Latin America.

13 Multinational company with headquarters in the United Kingdom. It works principally in five areas in the mining field: Platinum, coal, iron, diamonds, and base metals. In Colombia, there is only exploration of oil and other metals and minerals. 
Compact,${ }^{14}$ the Voluntary Principles for Security and Human Rights in the Extractive Industry, ${ }^{15}$ Global Reporting Initiative $\mathrm{GRI}^{16}$ and Transparency Initiative for the Extractive Industry TIEI. ${ }^{17}$

One outcomes suggested by the investigation is that the soft law has become a powerful language which serves as a device that allows TNCs to deceitfully champion the course of their activities to appear as if they are committed to the protection and guarantee of the HR. Thus,

14 Global compact was presented in 2000 by the United Nations Secretary, Kofi Annan. Its goal is to unify businesses and the UN in a mission to promote the positive role business can play in the protection of human rights and the environment. It tries to voluntarily commit the business leaders to observe principles related to human rights, work and environmental and anti-corruption regulations. Nolan, J., “The United Nations' Compact with Business: Hindering or Helping the Protection of Human Rights?" Queensland Law Journal, vol 24, 2005, p.446-456-9

15 Voluntary principles for security and Human Rights in the Extractive Industries. They respond to an initiative that started in 2000 by the governments of the United Kingdom and the United States. Nine non-governmental organizations of human rights and work organizations such as Amnesty International, Business for Social Responsibility Human Rights Watch, The International Federation of Chemical, Energy, Mine Workers Union and Prince of Wales international Business forum and mining companies of Oil and Gas such as BP, Chevron/ Texaco, Royal Dutch/Shell, Rio Tinto. The initiative tried to establish a preventive framework in human rights derived from the results of the investigations of the NGOs on extractive companies, which focused on the violation of indigenous' rights, environmental impacts, security, distribution and corruption issues, and in general the transnational company shall operate in zones with deplorable records. Williams A., "Civil society initiatives and "soft law" in the oil and gas industry”, International Law and Politics, vol. 36, 2003-2004, Pp. 461-477

16 The initiative of Global Reporting GRI responds to a group of investors who are working on creating and mastering a form, which is consistent and comparable so that companies can use it as a voluntary report through which the social, economic and environmental impact is incorporated using some indicators. This is an initiative that gathers companies around the world, NGOs, accounting firms, investors and work institutions and agencies of some governments such as the USA Labor Department, International Work Issues Department and the French Minister of Environment and the United Nations Environment Programme UNEP. Ibidem, p. 471.

17 The Extractive industry transparency initiative EITI-, was originated in the British government in 2002, when it tried to gather oil companies, international organizations such as World Bank, IMF, investors and NGOs to develop a framework to report revenue collection and payments the extractive sector makes. It is oriented to establish transparency in information channels in order to communicate what companies pay to governments in host countries. It is led by 120 NGOs, guided by Global Witness a NGO. The initiative pretends to compensate disparities that exist in the distribution of resources between rich and poor countries. It is mainly determined by governments' corruption. Ibidem, pp. 471-484 
based on the implementation of these with the rhetoric employed in CSRs, they adopt guiding principles or guidelines for carrying out their activities. Theses guidelines appear to serve as a mechanism for selfregulation and enhancing one's reputation, proving the last aspect with a good level of efficiency. The above conclusion was the result of the views expressed by the companies themselves:

These companies understand the definition of soft law. When questioned about their content and implications, Company A said that they are "voluntary initiatives". They understand that once the adhere to them, it is necessary to observe them: "I can adhere or not adhere to them and once the company adheres to them, they become part of the corporate ethics; and noone can say that we failed to meet the requirements stated since they are completely voluntary. If they are not going to be observed, they are not part of the company." Company D said that even if soft law does not consist on "legal rules," its flexible nature is not completely real since these instruments are used to create a frame, or series of non-binding agreements between the company and the government, referring to the Voluntary Principles on Security and HR.

Company B said that these international efforts are crucial to the company's corporate image. When asked about the reasons for incorporating these instruments, they indicated that companies are characterized as being in violation of HR, or remove the communities where they are settled to favor their economic interests. To change that image, they began to adhere to these international initiatives under the policy of respect for HR and improve their relationships with the communities. They further argued that their compliance with HR defines that any NGO can easily verify what the company is doing in the field. Additionally according to the interview, these checks could be used to counteract the bad images which are created by the media.

Corresponding to the previous idea, the relationship of soft law instruments provides major reputational implications for companies in terms of HR. In the current scenario the perception and criticism of bad practices can be more devastating than the consequences of a lawsuit. Thus, for Company A, HR violations that come to international bodies like the stock market where the share is quoted are almost irreparable, as it is in the stock market, where they compete with their 
peers, she said, "there is a pressure to shareholders, the share price falls". Company B for their part, said that while there are no legal sanctions for noncompliance with the built-in instruments, there are worse outcomes, such as the actual demise of the company. The representative of this company emphatically stated that a branded company accused of violating human rights may disappear, because the share price falls and with it, "the price of the company drops to the floor", which results in the company no longer being viable. He added that in the worst case scenerio, the company must leave the country.

Taking into account the arguments presented above, it can be said that the impact of soft law instruments, in terms of efficiency, is not measured by the means that exist to require companies to comply with them and the consequent sanctions imposed by an authority. By contrast, efficiency, seen as a "socially valuable state of affairs", ${ }^{18}$ shows that companies empower the role that the initiatives taken up by them mark them, so that the need to build a reputation over the same leads them to become self-regulating over the exercise of their activities. As a result of the impact of soft law instruments, translated into CSR, the inclusion of the HR in the IIA does not transform the actions taken by conmpanies, if we take into account that they do it for reputational reasons. Once the reasons and consequences for which companies link their human rights to their practical initiatives are stated, it will discuss the relationship between soft law and IIAs.

\section{Soft law and International Investment Agreements}

Advances in HR issues, including those under international agreements and initiatives, are not quite sufficient when they are analyzed in light of their enforceability. For enterprises, the lack of binding effects in the drafting of the terms, strengthen their CSR activities. Enforceability is not the first concern of the states, instead, it is the inclusion of HR issues that allows them to respond progressively to community concerns

18 Navarro, P., La eficacia del Derecho (Law Efficiency), Madrid, Centro de Estudios Constitucionales, 1990, p. 19. 
regarding the challenges of the non-state actors activities such as TNCs. Likewise, the formulation of such items allows them to build and strengthen their image of leadership in the international community and in turn, develop an identity.

In this respect, the recently signed agreements such as CARIFORUM ${ }^{19}$ Comesa, ${ }^{20}$ the Protocol to the Finance and Investment, ${ }^{21}$ FreeTradeAgreement-NAFTA between Canada and Colombia, are betting on the inclusion of clauses in regulating the investor's behavior(CARIFORUM, ${ }^{22} \mathrm{Comesa}^{23}$

19 The purpose of this association agreement among the state members of CARIFORUM and the European Union is to promote regional integration by establishing a transparent regulatory framework for trade and investment, determining a clause called investor behavior and another one related to natural resources exploitation.

20 The state members are: Republic of Burundi, Union of Comoros, Democratic Republic of the Congo, Republic of Djibouti, Egypt, State of Eritrea, Ethiopia, Kenya, Libya, Madagascar, Malaui, Mauritius, Rwuanda, Seychelles, Sudan, Swaziland, Uganda, Zambia and Zimbabwe, Members of the Common Market for Eastern and Southern Africa.

21 Its goal, among other things, is the harmonization of the financial policies and investments in the state members to make them consistent with the SADC (Southerm African Development Community) goals.

22 Article 72. Behavior of investors

"The EC Party and the Signatory CARIFORUM States shall cooperate and take, within their own respective territories, such measures as may be necessary, inter alia through domestic legislation, to ensure that:

(a) Investors be forbidden from, and held liable for, offering, promising or giving any undue pecuniary or other advantage, whether directly or through intermediaries, to any public official or member of his or her family or business associates or other person in close proximity to the official, for that person or for a third party, in order that the official or third party act or refrain from acting in relation to the performance of official duties, or in order to achieve any favour in relation to a proposed investment or any licenses, permits, contracts or other rights in relation to an investment.

(b) Investors act in accordance with core labor standards as required by the International Labour Organization (ILO) Declaration on Fundamental Principles and Rights at Work, 1998, to which the EC Party and the Signatory CARIFORUM States are parties.

(c) Investors do not manage or operate their investments in a manner that circumvents international environmental or labour obligations arising from agreements to which the EC Party and the Signatory CARIFORUM States are parties."

23 The agreement creates a common investment area among Comesa governments, recognizing the importance of direct investment as a source of funding oriented to maintenance of economy, industry, infrastructure, technology development. Article 13 Investor Obligation

"COMESA investors and their investments shall comply with all applicable domestic measures of the Member State in which their investment is made." 
and Protocol for the Financing) ${ }^{24}$ or advises the states (FTA between Canada and Colombia) about the obligation to promote the involvement of internationally recognized standards of CSR companies within their jurisdiction. Article 816 of Colombia-Canada FTA notes: ${ }^{25}$

Each Party shall encourage enterprises operating in its territory or subject to its jurisdiction to voluntarily incorporate internationally recognized standards of corporate social responsibility within their internal policies, such as statements of principle that have been approved or are supported by the Parties. These principles address issues such as labor rights, environment, human rights, community relations and combating corruption. The Parties shall remind those companies the importance of incorporating such standards of corporate social responsibility in their internal policies.

Comesa agreement has a much more advanced design for business commitments, even though it has limited enforceability. This agreement does not speak directly of HR violations by investor, but allows that of the member state should be sued by an investor of Comesa, to present a defense or counterclaim of an investor breach of its obligations under the agreement, or breach of those acquired with the host state, or lack of care to take reasonable steps to mitigate possible damage. ${ }^{26}$

24 In its article 10 attachment 1 , it includes a clause related to corporate responsibility, foreign investors shall aim by law, regulations, administrative guidelines and policies of the host country.

25 Available at: http://www.mincomercio.gov.co/econtent/NewsDetail.asp?ID=6779, checked on October, 2010.

26 Article 28 Investor-State Disputes 1. In the event that a dispute between a COMESA investor and a Member State has not been resolved pursuant to good faith efforts in accordance with Article 26, a COMESA investor may submit to arbitration under this Agreement a claim that the Member State in whose territory it has made an investment has breached an obligation under Part Two of this Agreement and that the investment has incurred loss or damage by reason of, or arising out of that breach by submitting that claim to any one of the following for at a time.

9. A Member State against whom a claim is brought by a COMESA investor under this Article may assert as a defence, counterclaim, right of set off or other similar claim, that the COMESA investor bringing the claim has not fulfilled its obligations under this Agreement, including the obligations to comply with all applicable domestic measures or that it has not taken all reasonable steps to mitigate possible damages. 
Under the wording of the agreement it is unclear the type of procedure and liability for the investor. This is because the agreement does not specify whether that breach of the obligations undertaken by the investor is related to commitments on issues of $\mathrm{HR}$, and in case of such a relationship. It is unclear whether the complexities and consequences of unfulfilled obligations must be resolved by an arbitral tribunal or a domestic court. Then, in case the court is competent, it might leave his unfinished powers in matters of HR. Finally, the wording suggests that the liability arises towards the state, leaving out the victims and their subsequent compensation.

In relation to the initiatives, the Institute for Sustainable Development IISD has developed the Model International Agreement on Investment for Sustainable Development 2005. ${ }^{27}$ This model, among other aspects, deals with civil liability for damage caused by the investor including both natural and legal persons. ${ }^{28}$ However, it leaves investor's homeland as the host or the jurisdiction of the lawsuit. ${ }^{29}$ Taking this into account, the IISD proposal, which appears to make significant progress, actually leaves contentious issues unresolved: on the one hand, it formulates a CSR clause that can be understood as a statement of parameters for good behaviour but offers questionable enforceability with the additive that makes reference to certain international instruments of soft law as the business guidelines. ${ }^{30}$

27 Cosbey A., Mann H., Moltke K., and Peterson L., IISD Model International Agreement for Sustainable Development, Canada, International Institute for Sustainable Development, 2005.

28 Article 2 "definitions" in part D, it points out that that the Investor is a national or company from the head state which makes or is making the investment within the territory of another different state.

29 Article 17: "Investor liability. Investors shall be subject to civil actions for liability in the judicial process of their home state for the acts or decisions made in relation to the investment where such acts or decisions lead to significant damage, personal injuries or loss of life in the host state".

30 Article 16: "Corporate social responsibility

(A) In addition to the obligation to comply with all applicable laws and regulations of the host state and the obligations in this Agreement, and in accordance with the size, capacities and nature of an investment, and taking into account the development plans and priorities of the host state, the Millennium Development Goals and the indicative list of key responsibilities provided in Annex F, investors and their investments should strive to make the maximum 
On the other hand, it attributes to the investment home state of the jurisdiction to hear any claims against the investor. It results in procedural obstacles and a persistent cancellation of justice. In terms of obstacles, it assumes that the trial will take place in the state of occurrence of events, thereby affording little opportunities for victims to access resources, and the collection of evidence to become very tedious. As for the cancellation of justice, a further consideration is that the investment-receiving states are usually developing states with weak or inefficient judicial systems. In this regard, if the jurisdiction were the host state with a considerable follow-up, these states will be forced to strengthen their judicial systems. Finally, the initiative does not solve the issue of representation of victims resulting from possible violations of the HR. ${ }^{31}$

Finally, the agreements mentioned allow to defend the idea that states are creating international regimes that meet the unique challenges of globalization and the inclusion of powerful non-state actors with the capacity of government interference and risk of harm or commit HR violations, such as TNCs. Under this view, the states aware of the asymmetrical relations between them and the TNCs keep largely protectionist structures which creates the IIA. This is an important key to capture and retain investments, however progress resulting from this inclusion of HR commitments is made in soft language. Likewise, the inclusion of HR commitments aimed at TNCs in international investment ins-

feasible contributions to the sustainable development of the host state and local community through high levels of socially responsible practices.

(B) Investors should apply the ILO Tripartite Declaration on Multinational Enterprises and Social Policy and the OECD Guidelines for Multinational Enterprises, as well as specific or sectoral standards of responsible practice where these exist.

(C) Where standards of corporate social responsibility increase, investors should strive to apply and achieve the higher level standards".

${ }^{31}$ It shall be considered that the victims are underpriviledged people, who have low educational levels, and some have a different cosmogony from the Western culture, such is the case of natives. In those cases, taking actions to compensate those victims is possible if there exists an institution in charge of assisting them by offering help and communication channels between them and complaint centers where violations by companies are reported.

Additionally, it is necessary to study the case of the states which are accomplice of HR violations with investors. In this scenario, it turns out illogical to think that the representativeness of the rights of the victims can be given by the government. 
truments but mediated by the states responds to issues of leadership and identity of states. ${ }^{32}$ The states are pledging for cooperation on certain issues to the extent they will achieve benefits, and therefore, be identified as good leaders. This in turn enhances their identity; that of being recognized as a friendly state in relation to securities or common structures to the international community. Thus, the incorporation of $\mathrm{HR}$ in the negotiating trade agenda or investment issues reflects that international leadership is not only achieved by accumulating material power or armaments empire but rather by being guarantors of human rights in the context of investment-trade.

\section{Bilateral TREATIES FOR PROMOTION AND PROTECTION OF FOREIGN INVESTMENT}

In the previous chapter, we studied the relationship between HR and IIA, referring to soft laws bound by the enterprises under the CSR, in order to distinguish the impacts caused by the inclusion of the HR in IIA's towards states and TNCs. This chapter will intend to make an introduction of BITs in order to illustrate the relationship between HR, BITs and arbitration of foreign investments. BITs constitute one of the largest IIA demonstrations to protect and guarantee the rights of inves-

32 In international relations, theories such as realism, liberalism and constructivism have been developed to explain relationships among the States. The constructivism theory, developed by international relations, points out that the interaction among the states, mediated by argumentative, explicative, and persuasive processes, is fundamental to create, define or modify ideas, behaviors, preferences and as a consequence the identity of states. The states constitutive nature allows them to be subject of continuous construction and revision of their identity. According to constructivism, when states have a defined identity, they comply with rules because they think they are doing what is correct, and that allows them to make a difference among their peers. Finally, states allow dynamics of strategic and argumentative interactions as mechanisms of achieving cooperation and meeting goals. Fearon J., and Wendt A., "Rationalism v Constructivism: A Skeptical View", in: Carlasnaes W., Risse T., and Simmons B. (eds.), Handbook of International Relations, New Delhi, Sage Publications, 2001, pp. 52-68 See also: Wendt A., "La Anarquía es lo que los Estados hacen de ella. La Construcción Social de la Política de Poder", Revista Académica de Relaciones Internacionales, núm 1, Marzo 2005, p. 1-28. 
tors. The more than 2600 treaties $^{33}$ that exist may give an indication of this and lead researches to investigate the reasons for its emergence, as well as the areas addressed and operational dynamics.

Its creation sought to be a solution for: 1.- the complexities arising from the exercise of diplomatic protection for the investor and 2.- the asymmetrical relationship between investor and state. With regard to the difficulties of diplomatic protection by BITs, the investor is given legal standing (ius standi) to initiate direct action of their rights ignored by the investment host states before international arbitration courts. ${ }^{34}$ In that sense, diplomatic protection, whose source is the consuetudinary international law, is the necessary dependence on the political will of the investor's homeland to get its representation in an international court and initiate legal action against the host state for lack of protection of their rights or an actual injury or violation. ${ }^{35}$

In addition to reliance on the political will of the state, the investor must first go before the national courts of the State receiving the investment and once they have exhausted the domestic remedies make a request to his homeland. Application which may or may not be considered as viable as the states are not required to attend on behalf of an investor (national). Additionally, the state may argue any tensions in the relationships with the violator state. Finally, some of the difficulties with diplomatic protection arise from cross-border exercise of investment activities. It is possible to establish subsidiaries in other countries, but it is not easy to know who should represent them. ${ }^{36}$

33 United Nations Conference on Trade and Development, International Investment Agreements:Assessment, op. cit., nota 3,4, p. 16

34 Dupuy, P., "Unification rather than Fragmentation of International Law? The Case of International Investment Law and Human Rights Law”, in Dupuy P., Francioni F., and Ulrich E. (ed.), Human Rights in International Investment Law and Arbitration, New York, Oxford University Press, 2009, pp. 47 y 48.

Dupuy clarifies that diplomatic protection was activated for the benefit of a national. It was not due to his condition as a person but due to his condition as a foreigner in the other country. This means, that in the current system, the person is protected under international law due to his nature as a human being. p. 47.

35 Ibidem, p.48

36 United Nations Conference on Trade and Development, International Investment Agreements, Key Issues, Vol 24, Geneva, UNCTAD, 2004, p. 348 
Considering the above, BITs constitute artifacts to empower investors to the extent that the contracting parties give those powers to them, but they were actually reserved to the states, as is, to initiate a complaint directly before an international arbitral tribunal, often without exhausting domestic resources ${ }^{37}$ by which investors are the only ones empowered to select the arbitration, ${ }^{38}$ by designing a model under which, in the absence of investor obligations in these treaties, the states will always be the passive subjects of the complaints because they are the ones who hold such obligations. The BITs as instruments to stop the obtacles of diplomatic protection, also arise from the asymmetrical relationship that exists between the investor and the states. States in their capacity as sovereign can change the law applicable to investors or influence international legislation affecting their interests, important reasons for the creation of treaties such as BITs, which regulate the possibility of compensating the weak or inferior status of the investor. ${ }^{39}$

Regarding the issues covered by the BITs, the regulation of the status of the host state investor focuses on: the definition or determination of protected investments, equal treatment between the foreign investor and the host state's domestic investor, the clause of the most-favored nation, the fair and equitable treatment, also known as the international minimum standards of treatment, safeguards against expropriation and compensation of the previous indemnity, ${ }^{40}$ the free transfer of investments and profits and the re-establisment of mechanisms for solving controversies between the investor and the host state as well as between the contracting states. In this respect, the inclusion of commitments in HR in charge of the contracting states or investor is not a priority due to the BITs protectionist nature rather than their enforcing nature.

\footnotetext{
37 Van Harten, G., Investment Treaty Arbitration and Public Law, New York, Oxford University Press, 2007, p. 50, 110

38 Mann, H., International Investment Agreements, cit., p. 4.

39 Hirsch, M., "Investment Tribunals and Human Rights: Divergent Paths", in Human Rights in international Investment Law and Arbitration, cit., p. 98 y 107

40 Gray K., and Peterson L., International Human Rights in Bilateral Investment Treaties and in Investment Treaty Arbitration, Canada, International Institute for Sustainable Development, 2003, p. 8
} 
In relation to controversies that may be subject to arbitration under a BIT, there is a posibility that under the umbrella clause, violations to obligations arose through contracts between the state and an investor may be solved as a BIT violation. ${ }^{41}$ It means that in case the clause mentioned is included in a BIT, the jurisdictional competence of the court is extended because it will have competence over the violations made by the BIT and under the sues related to the violation of contracts. Those are violations of BIT by virtue of the clause. ${ }^{42}$ It allows the investor to ignore the domestic courts to dissolve the contractual controversy. In this way, a state could eventually be found liable for violating the international law because the violation to the contract becomes a violation to BIT by virtue of the umbrella clause. Once the essential features of BITs have been identified, it will discuss the relationship between HR, BITs and investment arbitrations.

\section{THE APPEAL TO HUMAN RightS AS A DEFENSE MECHANiSM OF THE PARTIES TO THE ARBITRATION OF FOREIGN INVESTMENT}

Bilateral treaties for the promotion and protection of foreign investment -BITs-try to balance the asymmetries between the investor and the state. When the structure imposes obligations on only the investment host state, it attempts to resolve the weak situation of the foreign investor towards a subject with sovereign powers. ${ }^{43}$ This suggests that the use of direct or indirect language of human rights by companies in arbitration would be a means to strengthen this weak status. However, the use of such language by the states and investors in investment arbitrations may have a double meaning: on the one hand, it can empower foreign investors by making them more visible in their situation of wea-

${ }^{41}$ Wong, J., "Umbrella Clauses in Bilateral Investment Treaties: Of Breaches of Contract, Treaty Violations, and the Divide between Developing and Developed Countries in Foreign Investment Disputes", George Mason Law Review, vol. 14, 2006. Available at: http: //ssrn.com/ abstract $=1260897$, p. 152

42 Ibidem, p. 40.

${ }^{43}$ Hirsch, Investment Tribunals and Human Rights, op. cit., pp. 98, 107. 
kness against the state. On the other, the referral by the state to a language indirectly supported on human rights or rhetoric created around it proposes a change in the logic of investment arbitrations in the sense that the guarantee nature of the BITs is challenged by the protection of public fudamental interests protected by the states with special reference to economic, social and cultural rights.

To address both perspectives or situations, first, it will be necessary to refer to the systemic integration of the international investment made by international law though referral to legal scenarios that are foreign in principle but would allow to fix the content, scope and limits of rights developed from values or principles identified as relevant for international law. Third party auditors are included in an arbitration under the legal entity of Amicus and as determinant means for such systemic integration by the arbitrators. In a second step, we will refer to two awards: Glamis Gold vs United States, and Piero Foresti vs South Africa.

\section{Systemic integration of international investment law by referral to human rights}

In the case of investment arbitration based on BITs, arbitrators are induced to appeal to other systems, such as human rights, since it is not possible to determine the content of rights as expropriation or fair and equitable treatment by reference only to the provisions of the bilateral treaty. Additionally, figures as amicus curae become a means to illustrate the tensions between public and private interests involved in an arbitration. With regard to referral to other schemes, the Convention on the Settlement of Investment Disputes, ICSID in Article $42^{44}$ allows the absence of agreement between the parties on applicable law to be

44 Article 42. "(1)The court shall decide the difference according to the right regulations agreed by the parties. In case of no agreement, the Court shall apply the State legislation which is part in the difference, including its private international law regulations and the applicable international law regulations.

(2) The Court will not be able to exempt to fail under pretext of acceptability or ambiguity of the law.

(3) The dispositions of the precedents separated from this Article will not prevent the Court, if the parties agree on it, to decide the difference ex aequo et bono. Available at : 
possible to refer to the right of the state that is party to the difference, as well as international law as applicable. The reference to international law is understood under the context of the sources provided for in Article 38 of the Statute of the International Court of Justice..$^{45}$ Thus, making it feasible for the integration of consuetudinary international law, treaties and jurisprudence of international courts. Hence, the reference to human rights treaties and norms of ius cogens acquires explanation. ${ }^{46}$ With regard to domestic law, Dupuy notes that in treaties that make reference only to the right of the host state of the controversy as a means to determine the law applicable to the dispute, the integration of international arbitration can be done, as is usually recognized in the constitutions of the states in the primacy of international law. ${ }^{47}$

To place this in context in the practice of arbitration in investment, integration of public international law to international investment law on the basis of human rights can be seen in the case Tecmed vs Mexico. The controversy was the lawsuit filed by Tecmed (Spanish company) against Mexico. The lawsuit was backed by arguing BIT expropriation in court under the ICSID. It was argued that Mexico, argumenting environmental reasons, did not allow this company to continue its activities in wastewater treatment. In order to ensure the fairness and proportionality of the measure and emphasizing the condition of weak investor, the arbitral tribunal made reference to the James vs United Kingdom case decided by the European Court of Human Right -ECHR-, in which it warns that in the events of expropriation, it is necessary to distinguish that the nationals are legally required to support more public burdens than individuals. ${ }^{48}$

In the case of Azurix vs The Argentine Republic, 2006, which was solved at a arbitration court under the ICSID, a U.S. company sued Argentina arguing that Argentina was in violation of the BIT agreed with

http: / /icsid. worldbank.org/ICSID / FrontServlet?requestType=ICSIDDocRH\&actionVal= RulesMain.

45 Pierre -M., Unification Rather than Fragmentation of International Law?, cit., pp. 56 y 57.

46 Idem.

47 Ibidem, p. 59.

${ }^{48}$ Hirsch, M., Investment Tribunals and Human Rights, op. cit., p. 101 See: Tecmed vs. Mexico. ICSID Case ARB(AF)/00/2. Final sentence, paragraph 122. 
the USA. Argentina infringed the right to expropriation with compensation, the fair and equitable treatment and the right to full protection and security. The company was a distributor of drinking water and in charge of wastewater treatment in Argentina. ${ }^{49}$ The court of arbitration decided to take the jurisprudence of the ECHR to determine whether regulatory actions could be read as an expropriation and give rise to compensation. ${ }^{50}$ Argentina in their defense made use of arguments related to the $\mathrm{HR}$, saying that the investment treaty termination was justified by the need to protect consumer rights. According to Argentina, a conflict between a BIT and HR should be resolved in favor of $\mathrm{HR}$, since the consumer public interest must prevail over that of private interests. ${ }^{51}$ Additionally, the distinction was made between legitimate regulation and confiscatory. ${ }^{52}$ The court of arbitration then referred to the jurisprudence of the ECHR to establish the proportionality of the measures pursued in the public interest, ${ }^{53}$ taking as reference the case James vs United Kingdom which was quoted in the arbitration Tecmed vs Mexico. A ruling was brought up by the ECHR to give content to the right to property. ${ }^{54}$ Finally, the court of arbitration defended his idea saying that the case was not about expropriation but whether there was a violation of a fair and equitable treatment and full protection and security. ${ }^{55}$

In the case Mondev, a Canadian company sued the United States before a court of arbitration under the ICSID based on NAFTA, saying

49 Anderson S., and Grusky S., Challenging Corporate Investor Rule, How the world Bank's Investment Court, Free Trade Agreements, and Bilateral Investment Treaties have Unleashed a New Era of Corporate Power and What to Do about it?, Washington, food\&waterwatch and The Institute for Policy Studies, 2007, p. 15.

${ }^{50}$ Reiner C., and Schreurer C., "Human Rights and International Investment Arbitration", in: Dupuy Pierre-Marie, Francioni Francesco and Ulrich Ernest (ed.), Human Rights in International Investment Law and Arbitration, cit., p. 102.

${ }^{51}$ Hirsch, Investment Tribunals and Human Rights: Divergent Paths, cit., p. 103.

52 Anderson and Grusky, Challenging Corporate Investor Rule, op. cit., p. 15

53 United Nations Conference on Trade and Development, Select Recent Developments in IIA Arbitration and Human Rights, IIA Monitor núm. 2 (2009) International Investment Agreements, New York and Geneva, UNCTAD, 2009, p. 5.

${ }^{54}$ Ibidem, p. 6.

55 Anderson and Grusky, Challenging Corporate Investor Rule, op. cit., p. 15. 
there existed a violation of minimum standards of treatment under Article1105 of NAFTA and the configuration of an expropriation. The court of arbitration referred to the jurisprudence of the ECHR in order to obtain clarity on the retroactive application of a new law to a contract, as well as to perform an analysis on the immunity of public officials. ${ }^{56}$ In the arbitration ADC vs Hungary, before a court of arbitration constituted under the ICSID, the plaintiff accused Hungary of expropriating their investment in a project aimed at building an airport in Budapest. The court of arbitration, to declare the defendants liability, referred to the jurisprudence of the ECHR in order to support the affected party>s right to due compensation due to expropriation. ${ }^{57}$ However, it is necessary to clarify that the integration that makes the court of public international law on the basis of human rights must be understood considering that it is not made under the construction of a doctrine or theory about it. The reference to certain passages of human rights jurisprudence is too much without becoming a hard core doctrine for decisions. This indicates that the systemic integration mediated by the need to go to other areas in order to determine the scope and content of certain rights linked to human rights is conducted in a cautious manner. This appears not to be surprising given the structure of international investment.

With respect to the legal entity of Amicus, International Centers for Arbitration of investment such as the ICSID has accepted his involvement in the process. ${ }^{58}$ Sometimes the arbitrators accept the intervention of third persons, organizations such as NGOs, which are not directly

${ }^{56}$ Mondev International Ltd $\mathrm{v}$ the United States. ICSID Case N. ARB(AF)/99/2. Sentence, paragraphs 138-144.

57 ADC Affiliate Limited and ADC \& ADMC Management Limited - v. - Hungry. ICSED Case N. ARB/03/16. Sentence, paragraph 497

Among other cases, we find: Siemens v The Argentine Republic, Channel Tunnel v France and the United Kingdom, Sempra v The Argentine Republic, Maffezini v Spain, See also: Moshe. Investment Tribunals and Human Rights: Divergent Paths. En: Human Rights and International Investment Law and Arbitration.

58 Rule 37 Visits and investigations; presentations by the non- opposing parties ..."(2) After consulting both parties, the Court can allow a person or entity which is not to be part of the difference (this rule is called "non-opposing party)" to make written presentation before the Court, consisting on issues related to the difference». 
involved in the dispute ${ }^{59}$ but can make valuable contributions to solve conceptual doubts, noting that this does not mean the entailment of their arguments. Urueña, says that the participation of third parties in the arbitration reveals the influence they have on the mentality of investment arbitration rather than a subsidiary role or as a mere instrument of legitimacy, but as a means to express substantial vision of the world that he calls "narrative of public interest in international law." ${ }^{60}$ Participation is the means to include a narrative of public interest that is beyond mere conflict of private actors ${ }^{61} \mathrm{He}$ adds that such participation improves the quality of a decision, because of the information provided, just as increasing transparency within the process, provides accountability and control by other branches of government. ${ }^{62}$

Despite the arguments of amicus are not binding, they are an important contribution since they become conceptual tools and broadcasters of a narrative of public interest as Urueña expressed it. For the case Glamis Gold the Quetchan Indian Nation as a trust of amicus, they said that the Convention 169 requires states to protect the rights and territories of indigenous communities. Hence, according to the intervention, the measures taken by the government of California should be approached with that perspective. ${ }^{63}$ The court at the time of accepting the

59 Harrison, J, Human Rights Arguments in Amicus Curiae Submissions: Promoting Social Justice? In: Human Rights in International Investment Law and Arbitration, op. cit, p. 400

${ }^{60}$ Urueña, R., "You'd better listen: Notes on the Mainstreaming of Public Participation in Foreign Investment Arbitration", International Law, Revista Colombiana de Derecho Internacional, núm 16, 2010, p. 339.

${ }^{61}$ Ibidem, p. 320.

62 Ibidem, p. 304-5.

Harrison James exposes three reasons why intervention is accepted: 1.- Public interest or the public importance of the topic as a key to decide the topic under controversy. 2.- Expertise and perspectives that amicus could bring, which would be important to assist arbitrators to make the right decision. 3.- It can contribute to improve transparency in the process in cases of high public interest. Harrison, James. Human Rights Arguments in Amicuto assist s Curiae Submissions: Promoting Social Justice? In: Human Rights in International Investment Law and Arbitration, op. cit., , p. 396-405.

Among the cases in which it has been used, we find: Aguas the Argentine Republic v The Argentine Republic ICSID, Biwater v Tanzania, Suez Vivendi v The Argentine Republic and Suez Interagua v Argentina, Glamis Gold v the United States.

${ }_{63}$ United Nations Conference on Trade and Development, International Investment Agreements, Business and Human Rights, cit., p. 28 
intervention did not elaborate on HR, but said that acceptance of amicus does not constitute an agreement or disagreement on the merits. ${ }^{64}$ The court at the time of accepting the intervention did not elaborate on HR, but said that acceptance of amicus does not constitute an agreement or disagreement on the merits.

The reading to the actions of third parties as a trust of amicus, results in the mobilization of international law and HR. The third party are involved as agents, who because of their expertise achieved to persuasively promote the inclusion of the HR in scenarios that based on their structures are reflected in disagreement with such possibility. Then they become relevant subjects to illustrate the tensions between public and private interests and the scope of international instruments that are incorporated into the discussion. In this sense, they act as a means to achieve the effectiveness of an instrument or a common discourse. They also contribute to the transformation of understandings rooted in areas or subjects that are born devoid of foundation in public law. At the time they act as agents that strengthen the internal regulation of the states, while respecting international law. This is the situation experienced by the case of Piero Foresti vs South Africa, explained later.

\section{Human Rights as artifacts of empowerment of foreign investors?}

As we noted in the introduction of this section, the purpose is to demonstrate that the use of a language or a logic aimed at human rights in investment arbitrations may have a dual orientation: 1-They can empower foreign investors making more visible the situation of weakness towards the state. 2- The remission by states to develop language indirectly relied on HR and supported in the defense of the rights of minorities shows a change in the dynamics for protectionist investment arbitrations. Under the first statement BITs compensate the imbalance of power and investor-state powers, giving the possibility for the manager to be the caretaker of their rights in a relationship that has meaning

${ }^{64}$ Harrison, "Human Rights Arguments in Amicus Curiae Submissions: Promoting Social Justice?”, cit., p. 404. 
in one way: only the state hosting the investment is obligated. To that extent, most of the rights provided by a BIT, that means fair and equitable treatment, most favored clause, minimum standard of treatment, prohibition of discrimination and access to judicial proceedings which are designed to protect investors but are vaguely worded and are themselves indeterminate.

In search of content and the limits of the rights mentioned, the remission by investors to an argumentative theory built around human rights, strengthens their weakened status. Here it should be noted that the rights which counteract the asymmetries between investors and state, have an argumentative burden in HR even if it is not mentioned directly. It cannot be denied that a minimum standard of treatment, or the concept and scope of discriminatory treatment are related to rights of equality, the notion of justice, the recognition of a particular condition of a subject as opposed to a mere object and thus a particular treatment, etc.

However, the above scenario is challenged in cases such as Glamis Gold vs. the United States and Piero Foresti vs South Africa, in which investors sought to demonstrate an expropriation and a violation of fair and equitable treatment using a rhetoric with some connection in HR but lost power over the significance of the reasons that supported the interests pursued by the states. Thus, based on the two cases mentioned, the paper intends to demonstrate that states in an investment arbitration supported in a BIT are not always doomed to be losers, because they are only ones required under the treaty. BITs and investment arbitrations as instruments designed to counteract the disadvantage of an asymmetric investor may end up empowering the states in a scenario in which they are not disadvantaged through the vindication of the rights of minority groups traditionally discriminated by the state and the society.

\section{A. Case Glamis Gold vs the United States}

Glamis, a Canadian mining company, relied on NAFTA and questioned before a court of arbitration constituted under the ICSID certain environmental protection and cultural measures taken by the government of California in relation to its mining industry. The state of Califor- 
nia considered viable the suspension of business activities based on the cultural impact of the project on the Quechan Indian community. The company in turn, claimed to have been expropriated of their rights in the gold mine and the denial by the U.S. government of fair and equitable treatment under Article 1105 of NAFTA. ${ }^{65}$ In their defense the plaintiff, at first, claimed the right to fair and equitable treatment based on international law, and second sought to apply this argument to the case without being able to prove such a situation before the court. Thus, regarding the scaffolding of fair and equitable treatment, they said it is a rule of consuetudinary international law, ${ }^{66}$ supported by a "minimum standard of treatment." They said fair and equitable treatment include interrelated and dynamic obligations(they cannot be read statically) of porvision, including: protection against arbitrariness and discrimination, access to an appropiate process, protection of expectations on investment and a transparent and predictable framework for them. ${ }^{67}$

When defending the arbitrariness in the context of fair and equitable treatment, they indicated that this is set when an action is being a grossly unfair, unjust, clearly improper and disecreditable. ${ }^{68} \mathrm{With}$ regard to the protection of legitimate expectations, it relied on the preamble of the NAFTA treaty to infer the need to maintain predictable commercial framework when starting an investment project. For this, they emphasized the Tecmed verdict. ${ }^{69}$ Then, referring to the situation, they said that the state of California violated the fair and equitable requirement to make the cultural review of the Imperial Project in a non-transparent and arbitrary way. ${ }^{70}$ They added that the design of environmental plans was governed by the law in effect at the time of initiating the project and its intention to adjust the project on two occasions to the requirements of law and the plans for land use. ${ }^{71}$ As additional protection, they said that according to a study by an expert archaeologist, the Imperial Project was

65 Glamis Gold, Ltd. v United States. ICSID. Case, Sentence. June, 2009.

${ }_{66}$ To this respect, the claimant added that this principle was recognized in more than 2000 treaties. That is why legal consciousness was more obvious.

67 Ibidem, Paragraph 542.

68 Ibidem, Paragraph 585, see paragraphs 788 and 627.

69 Ibidem, Paragraph 568.

70 Ibidem, Paragraph 663.

71 Ibidem, Paragraph 636-7. 
no different to cultural impacts than nearby mining projects, as the archaeological manifestations of the project were identical to neighboring projects. ${ }^{72}$

The defendant for its part, without referring directly to the economic, social and cultural rights, referred to the right of the indigenous community to conserve and protect Quechan sacred sites. Thus, they argued that the cultural review of the project allowed for the identification of the "path of the dreams" of the Quechan, and the spiritual significance of the project area. ${ }^{73}$ They then added that the cultural review of the 1997 project, carried out by archaeologists, confirmed that the Quechan experts considered the Imperial Project area spiritually significant, partly because it was plugged into his path by which members of the tribe traveled through their religious practices. ${ }^{74}$ The defendant also said that the differential treatment given to the Imperial Project with respect to the others was based on: .- The dense archaeological features of the project area: they got evidence that in the past it was used for religious and ceremonial purposes. 2.- The impact, the Indian American community expressed fears of the impact of the project. 3.- The overlap between the concerns of indigenous and archaeological evidence 4.The project is located in a non-mined area which has not been subject to significant mining activity. ${ }^{75}$

Finally, the court held that the Imperial Project was unique among other projects regarding cultural significance for a community. ${ }^{76}$ The court stressed that their decisions were based on the defendants serious cultural studies and the expertise of professional archaeologists and researchers. In closing, the court stated that the plaintiff failed to demonstrate that the cultural review of the Imperial Project reflects a flagrant denial of justice, manifest arbitrariness or gross injustice, a complete lack of due process or a clear discrimination in the light of international standards to constitute a violation of Article 1105 of NAFTA. ${ }^{77}$

72 Ibidem, Paragraph 647.

73 Ibidem, Paragraph 663-4.

74 Ibidem, Paragraph 668.

75 Ibidem, Paragraph 673.

76 Ibidem, Paragraph 780.

77 Ibidem, Paragraphs 788 and 627. 
It is an arbitration commenced by investors from Luxembourg and Italy against South Africa before an ICSID arbitral tribunal in 2007, based on the BITs signed by the defendant state with states mentioned. The investors argued they were dissatisfied with the measures taken by the government of South Africa under the Mineral and Petroleum Resources Development Act MPRDA, 2004, which requires that foreign mining companies allow the participation of black people in the mining sector under the agenda Black Economic Empowerment. Based on this provision, it is required that foreign investors sell-26\% by 2014-of their shareholding to black Africans and get the $40 \%$ of management in mining companies. ${ }^{78}$

This arbitration as opposed to Glamis Gold received no ruling on the merits, because it was suspended at the request of the plaintiff as a result of an agreement with the defendant. In their defense, the plaintiffs stated to be the victims of unfair and inequitable treatment, as well as direct and indirect expropriation because of the MPRDA. Plaintiffs argued that the legislation rendered obsolete in relation to the old mining regulation and instead expropriated of their rights in full and made it impossible to continue their activities. Based on both BITs, the plaintiffs expressed the reasons for a legal expropriation: 1- When performed on the basis of public purpose or national interest (BIT with Italy) or for a public purpose related to the internal needs of the country (BIT with Luxembourg). 2- When there are no discriminatory basis.3- Once it is made, the host country must immediately pay the full and effective compensation (BIT with Italy) or should promote adequate and effective compensation (BIT with Luxembourg) and 4- The expropriation must be undertaken through application of the appropiate process. ${ }^{79}$ Taking this into account, the plaintiffs reiterated that South Africa expropriated by issuing a new regulation incompatible with the old one and by requiring foreign investors to sell their $26 \%$ shareholding. They

78 Anderson and Grusky, Challenging Corporate Investor Rule, cit., p. 12-3. See also: Piero Foresti, Laura de Carli and others vs. South Africa. ICSID Case N. ARB (AF)/O7/1. Award.

79 Piero Foresti, Laura de Carli and others vs. South Africa. ICSID N. ARB (AF)/O7/1 Award, paragraph 58 . 
mentioned there were improper compensations, in addition to being victims of undue process and discriminatory measures. ${ }^{80}$

The South African government argued that the expropriation of the old order and the actions in the operating company meets multiple public purposes. It was stated that the promulgation of the MPRDA and the Mining Charter focuses on: i.- Simplifying and modernizing the regulation of mining. ii.-Reducing the negative social effects caused by the Apartheid in general and the regulation of mining rights in 1991, iii. Reducing the damage caused by the concentration of mining rights and promote the proper exploitation of mineral resources and IV. Protecting the environment and the communities surrounding mining operations. ${ }^{81}$ They further stated that it was not possible to talk of expropriation because: 1. A non-discriminatory regulation can not have an expropriation nature. 2. The plaintiffs were not deprived of their rights substantially and 3. No expropriation exists when the actions taken by the government are based on rational and proportional means to pursue legitimate public purposes. ${ }^{82}$

As for the Amicus, four $\mathrm{NGOs}^{83}$ submitted a petition to be admitted under limited participation in the arbitration. Their reasons respond to the implications of arbitration for the citizens of South Africa, civil society and the rest of the international community. Among the reasons for the application are: 1. The causes for which the MPRDA law was issued ${ }^{84}$ 2.- The objectives of the Constitution of 1996: sustainable development, environmental protection, substantial equity-home owner-

80 Ibidem, Paragraph 64-6.

81 Ibidem, Paragraph 69.

Additionally the government in South Africa stated that the legislation from 1991 could not be kept facing the coming into effect of a democratic organization. Regarding the compensations as a result of the expropriations, it was said that the government facilitated access to mechanisms to state them and it has been the parties who have not used them. Finally, they argued that the South African state has legal and administrative resources to debate the legality or pertinence of an expropriation. Ibidem, Paragraph 69-71

82 Ibidem, Paragraph 75.

83 The Center for Applied Studies, the Center for Environmental International Law, The Center for Human Rights Protection, and the Center for Legal Appeals.

${ }^{84}$ Mining Law MPRDA was enacted in South Africa due to public political reasons, supported by the necessity of issuing a new order after the Apartheid was over. The Centre for Applied Legal Studies CALS and others. Petition for Limited Participation as Non Disputing 
ship, elimination of discriminatory policies and the consequences of the Apartheid. 3. The international law powers and domestic law of the State of South Africa.$^{85} 3$-Relevance of the topic discussed in the arbitration for the international community. ${ }^{86} 4$ - Africa, Luxembourg and Italy are part of international HR treaties applicable to the case. ${ }^{87}$

The two cases involved let to infer that although the parties when presenting their defenses do not shore up by the use of direct language of HR. The truth is that there is an appeal to their logic and rhetoric built around them, with their referral, the parties intend to show that they are in a vulnerable position against its counterpart, which must be assessed in its favor. It is necessary to clarify that the state is the voice to account for the weak position of a minority group under its sovereign power, but in turn instrumentalize to avoid being found liable for a violation of a BIT. The defense of states endorsed in the general interest, relevant to a group (in keeping with its identity, its own history as with the Apartheid regime) and the international community shows that it can overcome the special interests of investors even if they are supported by international investment treaty.

In the cases Glamis Gold and Piero Foresti it becomes evident that the indirect scaffolding of International Human Rigths Law can tranform the private structure of the BITs and the investment arbitrations.

Parties in Terms or Articles 41(3), 27, 39 and 35 of the Additional Facility Rules, Oxford, 2009.

85 The Constitution authorizes taking legislative measurements and other measurements designed to reach equality. This means to eliminate discrimination, which includes a reform to property. The regime that emerged after the Apartheid grants authority to the government under domestic and international law to implement measurements which are oriented to compensate for the consequences of Apartheid. Ibidem, pp. 9-11.

${ }^{86}$ The topics discussed in this arbitration-HR and sustainable development v expropriation- involve all the international community because what they solve there might have impacts beyond a concrete case. Ibidem, p. 12.

87 Africa belongs to many international treaties which impose responsibilities related to protection and promotion of HR. Such is the case of the Convention that eliminates all ways of racial discrimination, the Civil and Political Rights Agreement, and the Convention for elimination of all ways of discrimination against women. Italy and Luxemburg belong to international conventions-the same as South Africa- which imposes not only the responsibility of promoting and respecting HR but also cooperating in the contribution of promoting them extraterritorially. Ibidem, p. 13 and 17 
In the first case, for the court, the cultural significance of the area of the Imperial Project acquired value facing the indigenous community. In fact, the court considered the studies and arguments of the defendant highly important. The defendant assured that the check of the project allowed them to identify the footpath of the dreams for the Quechan, as well as its spiritual meaning. In this case, the cosmogony of a minority group as an indigenous community became the justificatory argument of the state to order the cultural check of a project of foreign investment. The state without making use of the rhetorics around the social and cultural economic rights indicated the necessity to conserve and to guarantee the viability of the identity characteristics of an indigenous community against the impacts of a project. That is to say gave importance to the values, beliefs, religion, lifestyle of a group by opposition to the particular interests of an investor.

On the other hand the court, when studying the arguments of the parts, considered that the power of the national defense as well the archaeological evidence, consequently showed the particularities of the investment project compared to the other neighboring projects and the cultural meaning that the zone of the project had for an indigenous community. Of such way, the reference of the plaintiff to a discriminatory and arbitrary treatment at the time of the cultural check of the project, endorsed among others arguments, in the identity or similarity of its project with other neighbors, lost value facing a proof of a significant impact of the investing project in cosmogony of an indigenous group.

In the second case, the South Africa - even though this case was finished by an agreement between that met the requests of the plaintiff- without needing to be sent to a series of international instruments or direct argumentation in HR, it mentioned the consequences of the Apartheid for its region, relevance to eradicate them and to act in accordance with the dispositions of a democratic constitution. In this case, the fundamental public interest of a state became a justificatory argument to impose loads to the investors when it tried to give solution to the consequences of an excluding racial policy for a minority group. Thus, South Africa considered that its Constitution authorized the country to end the concentration of mining titles, and to promote 
the suitable operation of the mining resources offering access to the affected population. Finally, for South Africa the negative effects of the Apartheid had to be transformed in a system based on equality of opportunities for their citizens.

The cases Glamis and Piero indicate that the understanding of the logic of the BITs and investment arbitrations under a perspective in which there is only space for interests of a particular nature is not certain in all the cases and therefore, does not have to be generalized. The defense, on the part of the states for the rights of the minorities and the considerations of the court of arbitration to them, indicates that the investment arbitrations do not exclude the consequences of the potential victims of a project and as a result, it is possible to have a course change of an investment project. The previous reading can be interpreted, in a sense according to which, the states use the minority groups to avoid being declared responsible for the violation to a BIT; however, the fact that they can benefit does not have to exclude or reduce value to the vindication of the rights of the minorities.

Likewise the defense made by the states, in its intend to justify their decisions based on transcendental public intentions oriented to the rights of the minorities, allows to infer that they are in search of the balance of the benefits intended by the states in the investment projects. That happens because in the investment projects the rights or impacts undergone by the minorities, in most cases, are not relevant for the host state. In both cases, the balance intended by the state makes it include a subject alien to the bilateral treaty and the arbitration (as a part) but determining for the impacts undergone as a result of the project. What it can be observed is that the state and the legal entity of amicus-with their illustrating and documenting interventions- allow recognizing the impacts that victims could undergo due to an investment project. These impacts are normally annulled by the system. Thus, the situation of weakness of the investor activated in his behalf by the faculties conferred by the BITs can acquire a reverse (negative) by means of the defense of the rights of the minorities. The state ceases being aligned only with the interests of the investors to become more conscious of its self-defining reality. 


\section{CONCLUSIONS}

The modest or preventive inclusion of the HR in the IIAs suggests an effect oriented in strengthening the intention of the states in advancing toward a strategic agenda that allows them to build an identity and an international leadership. Nevertheless, such intention does not transform a scenario into which the companies include in their political activities of CSR with high HR content to protect their reputation and enterprise viability. This is a scenario that does not manage to be transformed since the IIAs leaves the demandability of the commitments created to the companies through the states are left unfinished.

Within an investment arbitration, the situation of inferiority of the investor, which is activated in his behalf by the faculties conferred by a BIT, can acquire a negative reverse effect by means of the defense of the public interests of the states endorsed in the rights of the minorities related to economic, social and cultural rights, without mention them directly. Thus, the indirect remission to the human rights on the part of the states can become: a.- a tool to its favor in a scenario where they are seen as constant losers, b.- a route to vindicate the rights of groups that normally are annulled by the system, c.- a scenario to superpose the identity character of a community over the interest's investors. Additionally, the appeal of the states to the defense of the minorities' rights inside arbitration to complement-the roll carried out by the Amicus shows that the investment arbitrations do not exclude the consequences of the potential victims of a project, and as a result, it is possible to change course of an investment project. Therefore, understanding the logic of the BITs and arbitrations of investment under a perspective in which there is only space for the interests of a particular character is not absolutely coherent.

According previous idea, the appeal of HR as a mechanism of defense of the parties in the investment arbitration can be understood in two contexts: under the first, the states, without referring directly to the hard core of ESCR, can create a coherent defense through the allusion of public fundamental interest of the minority people. In that sense, the defense for the states underpinned in the indirect language of HR 
or in the rhetoric created around them proposes a change in the logic of investment arbitration. Given that the structure of BITs suppose the states are losers. Under the second context, the investor may do more obvious his weakness status in related to the state, if he decides to articulate the rights in the BITS with the indirect language around HR that is the case of an expropriation.

\section{BIBLIOGRAPHY}

Articles, books and documents.

Anderson, Sara and GRUSKY, Sara, Challenging Corporate Investor Rule. How the world Bank's Investment Court, Free Trade Agreements, and Bilateral Investment Treaties have Unleashed a New Era of Corporate Power and What to Do about it?, Washington, food\&waterwatch and The Institute for Policy Studies, 2007.

Cosbey, Aaron et al., IISD Model International Agreement for Sustainable Development, Canada, International Institute for Sustainable Development, 2005.

DupuY, Pierre-Marie et al. (ed.), Human Rights in International Investment Law and Arbitration, New York, Oxford University Press, 2009.

DupuY, Pierre-Marie, "Soft law and the international law of the environment”, Michigan Journal International Law, vol. 12, 1991.

CARlasnaes, Walter et al. (ed.), Handbook of International Relations, New Delhi, Sage Publications, 2001.

Gray, Kevin and Peterson, Luke, International Human Rights in Bilateral Investment Treaties and in Investment Treaty Arbitration, Canada, International Institute for Sustainable Development, 2003.

KARMEL, Roberta and Kelly, Claire, "The Hardening Of Soft Law In Securities Regulation”, Brook. Journal International Law, vol. 34, 2008 2009, pp. 883-951.

MANN, Howard, International Investments Agreements, Business and Human rights: Key Issues and Opportunities, Canada, International Institute for Sustainable Development, 2008. 
Mondev International Ltd $v$ the United States. ICSID Case No. ARB(AF)/99/2 Sentence.

Navarro, Pablo Eugenio, La eficacia del Derecho, Madrid, Centro de Estudios Constitucionales, 1990.

Nolan, Justine, “The United Nations' Compact with Business: Hindering or Helping the Protection of Human Rights?", Queensland Law Journal, vol. 24, 2005.

OÑATE, Tatiana, "Instrumentos jurídicos para atraer la inversión extranjera”, (Legal Instruments to Attract Foreign Investment), Revista Foro de Derecho Mercantil, núm. 16, julio-septiembre de 2007.

The Centre for Applied Legal Studies (CALS), The Center for International Environmental Law (CIEL), The International Centre for the Legal Protection of Human Rights (INTERIGHTS), The Legal Resources Centre (LRC), Petition for Limited Participation as Non Disputing Parties in Terms or Articles 41(3), 27, 39 and 35 of the Additional Facility Rules. International Centre For Settlement Of Investment Disputes Case number: ARB(AF)/07/01 between Piero Foresti, Laura de Carli \& Others And The Republic of South Africa.

United Nations Conference on Trade and Development, Select Recent Developments in IIA Arbitration and Human Rights. IIA Monitor No. 2 (2009) United Nations Conference on Trade and Development. International Investment Agreements. New York and Geneva, UNCTAD, 2009.

, International Investment Agreements: Assesssment, Challenges and Path to Continue. Collection of publications of the UNCTAD on topics related to investment international policies on development, New York and Geneva, UNCTAD, 2008.

, International Investment Agreements. Key issues, vol. 24, Geneva, UNCTAD, 2004.

URUEÑA, René, "You'd better listen: Notes on the Mainstreaming of Public Participation in Foreign Investment Arbitration”, International Law, Revista Colombiana de Derecho Internacional, núm 16, 2010.

VAN HarTen, Gus, Investment Treaty Arbitration and Public Law, New York, Oxford University Press, 2007.

WENDT, Alexander, "La anarquía es lo que los estados hacen de ella (Anarchy is what states make of it). La construcción social de la política 
de poder (Social construction of the policy of power)", Revista Académica de Relaciones Internacionales, núm 1, marzo de 2005.

Williamson, Richard, "Hard law, Soft law and Non-Law in multilateral Arms Control: Some Compliance Hypotheses”, Chicago Journal International Law, vol. 4, 2003.

Williams, Cynthia, "Civil Society Initiatives and "Soft Law" in the Oil and Gas Industry", International Law and Politics, vol 36, 2003-2004, 457-502.

Wong, Jarrod, “Umbrella Clauses in Bilateral Investment Treaties: Of Breaches of Contract, Treaty Violations, and the Divide between Developing and Developed Countries in Foreign Investment Disputes”, George Mason Law Review, vol. 14, 2006. Available at: http: / /ssrn.com / abstract $=1260897$.

International Investment Agreements

Economic Partnership Agreement, CARIFORUM and the European Union.

Common Investment Zone Agreement among Comesa governments. Protocol for Financing the Southern Africa Development Community, SADC.

Free Trade Agreement between Canada and Colombia.

Arbitration awards

ADC Affiliate Limited - and - ADC \& ADMC Management Limited - v. - Republic of Hungary. ICSID Case No. ARB/03/16 Sentence.

Azurix Corp vs. The Argentine Republic. ICSID Case ARB/01/12 Decision on jurisdiction.

Glamis Gold, Ltd. v The United States. ICSID. Sentence. June, 2009. Piero Foresti, Laura de Carli and others vs. South Africa. ICSID Case No. ARB (AF)/O7/1. Sentence.

Suez, Sociedad General de Aguas de Barcelona S.A., and InterAguas Servicios Integrales del Agua S.A Vs. The Argentine Republic. ICSID Case No. ARB/O3/17. Sentence.

Tecmed vs. Mexico. ICSID Case ARB(AF)/00/2 Sentence. 